\title{
Atlantis
}

Critical Studies in Gender, Culture \& Social Justice

Études critiques sur le genre, la culture, et la justice

\section{Family Matters: Immigrant Women's Activism in Ontario and British Columbia, 1960s -1980s}

\section{Margaret Little, Lynne Sorrel Marks, Marin Beck, Emma Paszat and Liza Tom}

Volume 41, Number 1, 2020

URI: https://id.erudit.org/iderudit/1074022ar

DOI: https://doi.org/10.7202/1074022ar

See table of contents

Publisher(s)

Mount Saint Vincent University

ISSN

1715-0698 (digital)

Explore this journal

Cite this article

Little, M., Marks, L., Beck, M., Paszat, E. \& Tom, L. (2020). Family Matters: Immigrant Women's Activism in Ontario and British Columbia, 1960s -1980s. Atlantis, 41(1), 105-123. https://doi.org/10.7202/1074022ar

\section{Article abstract}

This article uses oral history interviews to explore the ways in which different attitudes towards family and motherhood could create major tensions between mainstream feminists and immigrant women's activists in Ontario and British Columbia between the 1960s and the 1980s. Immigrant women's belief in the value of the family did not prevent immigrant women from going out to work to help support their families or accessing daycare and women's shelters, hard fought benefits of the women's movement. However, these women demanded access to job training, English language classes, childcare, and women's shelters on their own terms, in ways that minimized the racism they faced, respected religious and cultural values, and respected the fact that the heterosexual family remained an important resource for the majority of immigrant women.

Immigrant women activists were less likely to accept a purely gender-based analysis than mainstream feminists. They often sought to work with men in their own communities, even in dealing with violence against women. And issues of violence and of reproductive rights often could not be understood only within the boundaries of Canada. For immigrant women violence against women was often analyzed in relation to political violence in their homelands, while demands for fully realized reproductive rights drew on experiences of coercion both in Canada and transnationally.
All Rights Reserved (c Margaret Little, Lynne Sorrel Marks, Marin Beck, Emma Paszat, Liza Tom, 2020

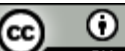

This document is protected by copyright law. Use of the services of Érudit (including reproduction) is subject to its terms and conditions, which can be viewed online.

https://apropos.erudit.org/en/users/policy-on-use/ 


\section{Family Matters: Immigrant Women's Activism in Ontario and British Columbia, 1960s -1980s}

Dr. Margaret Little is a Professor in Gender Studies and Political Studies at Queen's University and has been involved in anti-poverty activism for over 30 years. She is the author of the award-winning No Car, No Radio, No Liquor Permit: The Moral Regulation of Single Mothers in Ontario, 1920-1996 (Toronto: Oxford University Press, 1998) and If I Had a Hammer: Retraining that Really Works (Vancouver: UBC Press, 2005).

Dr. Lynne Marks is a Professor in the History Department at University of Victoria. She is the author of Revivals and Roller Rinks: Religion, Leisure and Identity in Late Nineteenth Century Small Town Ontario (U of Toronto Press, 1996) and Infidels and the Damn Churches: Irreligion and Religion in Settler British Columbia (UBC Press, 2017), as well as a range of articles and book chapters on topics related to the history of religion, irreligion, ethnicity, social welfare, gender, class and feminism in Canada.

Marin Beck is a PhD Candidate (ABD) in the Department of Political Studies at Queen's University in Kingston, Ontario, Canada, where she specializes in the Gender \& Politics and Political Theory. She is a SSHRC Joseph-Armand Bombardier Doctoral Scholar (2016-2019) and recipient of the Jean Royce (2016) and R.S McLaughlin (2015) fellowships. Her doctoral research explores the interplay of neoliberal practices and gender within immigrant settlement service organizations in Canada. She is currently serving as a Policy Analyst in Winnipeg, Manitoba, Canada on issues related to gender, race, and indigenous selfgovernance.

Dr. Emma Paszat is a Social Science and Humanities Research Council of Canada Postdoctoral Fellow in the Department of Social Science at York University. Paszat's research interests include politicized homo- phobias, LGBTQ politics, and decolonizing transnational LGBTQ activism.

Liza Tom is a $\mathrm{PhD}$ candidate in Communication Studies at McGill University. Her work looks at nongovernmental and community-based organisations that provide formal and informal support and services to transfeminine communities in Bangalore, and popular narratives of activism and welfare in urban India. Her work is funded by an FRQSC doctoral research scholarship.

Abstract: This article uses oral history interviews to explore the ways in which different attitudes towards family and motherhood could create major tensions between mainstream feminists and immigrant women activists in Ontario and British Columbia between the 1960s and the 1980s. Immigrant women's belief in the value of the family did not prevent immigrant women from going out to work to help support their families or accessing daycare and women's shelters, hard fought benefits of the women's movement. However, these women demanded access to job training, English language classes, childcare, and women's shelters on their own terms, in ways that minimized the racism they faced, respected religious and cultural values, and respected the fact that the heterosexual family remained an important resource for the majority of immigrant women.

Immigrant women activists were less likely to accept a purely gender-based analysis than mainstream feminists. They often sought to work with men in their own communities, even in dealing with violence against women. And issues of violence and of reproductive rights often could not be understood only within the boundaries of Canada. For immigrant women violence against women was often analyzed in relation to political violence in their homelands, while demands 
for fully realized reproductive rights drew on experiences of coercion both in Canada and transnationally.

Keywords: immigrant women, family, feminism, motherhood
$\mathbf{R y}$ the 1980s the staff at the Rexdale Women's B Centre (RWC) in Toronto surprised themselves by organizing their first men's group. "Would I have believed that we were having these services for men? Never, never, never. In my head it's a women's organization and women, women, women only. But I was wrong," laughs Fatima Filippi. Filippi is an immigrant herself who has been an immigrant women activist for almost 40 years and is now Executive Director of the RWC. "We did rights and advocacy particularly related to violence against women. And I remember one woman saying to me, 'I know my rights but I'm not punching myself in the face, it's the men who are doing it to us. Why aren't you doing something with them?' And so, she taught me, and we hired female and male facilitators to work with men and women in the immigrant communities to talk about violence" (Filippi 2016). Through this experience the staff realized that immigrant women's activism was distinct from other feminist activism of the 1960s through 1980s. Immigrant women were often concerned about the same issues as other feminists - paid work, violence against women, and reproductive rights. And yet, even when the issues were similar, the politics were organized in a manner that often centralized motherhood and family. This focus on motherhood and family was partly a result of the Canadian state's immigration and multiculturalism policies that defined and confined immigrant women's experiences. It also reflected other differences in experiences and perspectives between immigrant women activists and white feminists. This article explores how questions of family and motherhood were understood by immigrant women activists and shaped their politics.

In this article we examine the issues of paid work, violence, and abortion/reproductive rights primarily in the context of Toronto, Vancouver, and Victoria. This is our first article on issues related to feminism, immigrant women, motherhood, and family. It is part of a larger SSHRC-funded project that will examine these issues and related ones in five provinces. ${ }^{1}$ As a result, we see the findings in this article as a preliminary overview of a complex topic. We plan to explore these questions in more depth, with more regional diversity, and a more fine-grained lens over the next few years. This research involved archival investigation and oral 
history interviews. We conducted 50 oral history interviews, 25 with racialized immigrant women activists, and 25 with white feminists, all of whom were activists from the 1960s-1980s. The former were immigrant women who were active in immigrant women's services as social workers and organizational leaders. The latter included a few who defined themselves as immigrant women activists. The rest of the white feminists defined themselves as socialist or liberal feminists, active leaders in labour unions and/or local and national feminist organizations that we would now call "mainstream feminists" although they may not have defined themselves as such at the time. ${ }^{2}$

Our research is also based on liberal, radical, and socialist feminist journals, particularly Kinesis and Broadside, as well as in immigrant women's journals, including Diva and Tiger Lily. We also explored the National Action Committee on the Status of Women (NAC) newsletters and archival material, as well as archival material from other women's groups found in the University of Ottawa's Women's Movement Archives collection. We are grateful to the works by Tania Das Gupta (1986, 2007), Makeda Silvera (1989), Vijay Agnew (1996), Judith Ramirez, Roxanna $\mathrm{Ng}$ (1982), Micheline Labelle, and Martin Goyette (1993) and others for their important scholarly and political work about immigrant women's organizing. We are indebted to Canadian critical race scholars Yasmeen Abu-Laban (1998), Rita Dhamoon, Enakshi Dua and Angela Robertson (1999), Sherene Razack, Malinda Smith, and Sunera Thobani (2010) for addressing how the Canadian state and/or mainstream feminists have addressed race. ${ }^{3}$ We acknowledge that the first two authors of this article are writing this work from a place of relative privilege-while Lynne Marks immigrated to Canada in the 1960s as a young child, her South African Jewish parents were English speaking and middle class, her father an academic, and Margaret Little was born into an Ontario farming/settler family and the first generation to leave the farm and receive university education. We have been involved in some anti-poverty and feminist activism over the years, but recognize that we are relative outsiders to the story we tell here. In focusing on immigrant women's activism, we hope to contribute to work that is transforming our understanding of the history of "second wave feminism" in Canada, challenging the version of this history that Chela Sandoval calls "hegemonic feminism."4

There has been significant work on the history of immigration by Canadian historians and increasingly good work on the history of immigrant women. But there has been less work on immigrant women's organizations, particularly in the 1960 s to 1980 s, the period which saw the emergence of the second wave women's movement in Canada (Epp and Iacovetta 2016; Iacovetta 2006). Little attention has been paid to the absence of immigrant women from mainstream feminist organizations in Canada. In the postwar era, with a significant increase in immigration from Europe, there was a growing demand for support services for new immigrants. Most of the support work with new immigrants in the 1940s to early 1960s was done by professional Anglo-Canadian social workers and Anglo-Canadian volunteers. This work helped affirm the burgeoning social work profession and its expertise. Simultaneously, as Franca Iacovetta has argued, this immigrant support work attempted to shape newcomers into the postwar Anglo-Canadian ideal of immigrant citizens. ${ }^{5}$

This article focuses on the period immediately following the post-war era, the late 1960 s to the 1980s, when more immigrants began to arrive from Asia, the Caribbean, Latin America, and the Middle East. Even though the post-war era saw the expansion of the social safety net for white citizens, immigrant women often did not benefit from these new policies. During the immediate post World War II era an explicitly race-based immigration policy ensured that the majority of immigrants arrived from Europe, first from Britain and northern Europe and then increasingly from southern Europe. But the introduction of the points system in 1967 based on education, ability to speak English or French and job skills, officially eliminated racial barriers to immigration to Canada and European-born immigrants slipped from $90 \%$ of all Canadian immigrants prior to 1961 to $25 \%$ by the 1980s (Iacovetta 2006).

Canadian state policies during this era shaped immigrant women's identities and relationships to mother- 
hood and family. It is difficult to discern to what extent immigrant women actively chose their identities as mothers and the extent to which state policies deeply entrenched this familial identity. Either way, it is clear from our interviews and archival materials that immigrant women's activism during this era centralized motherhood and family. Both state policies of multiculturalism and immigration emphasized the maternal role of immigrant women. Multiculturalism became official Canadian state policy in 1971 and Canada reinvented itself as a welcoming nation for people of different races. But this multicultural policy was a new way of managing difference, transforming racial identities into cultural differences which contained and preserved "ethnic" cultures in a primitive and backward past while asserting whites as superior, tolerant and progressive (Abu-Laban 1998, 69-82).

Women of colour were always perceived as immigrants with distinctive cultures who were never fully, unquestionably accepted as full citizens (Ahmed 2000, 104). Consequently, multiculturalism defined immigrant women as preservers of culture through their familial duties. And the Immigration Act of 1976-77 defined immigrants into two main categories: the independent class and the family class. The independent class was designed to meet labour market needs and immigrants were approved based on a points system that calculated the applicant's level of education, occupation, and work experience. In contrast, the family class allowed immigrants already in Canada to sponsor family dependents into the country but he, and it was usually a he, was financially responsible for those he sponsored for up to 10 years. Thus, these sponsored immigrants had to rely upon their sponsor, rather than the state, for housing, food, clothing, and ultimately, survival. As such, the immigration rules reinforced the power of the male head of the immigrant family and ensured that most immigrant women were dependent within these families. Sponsored immigrants were denied welfare, housing, and old-age security and were restricted in their access to language and job-training programs (Thobani 2000, 134-138). The exception to these two immigrant types was immigrant domestic workers who, as independent workers, should have been defined under the point system but instead were in a separate category that defined them as temporary workers with severe restrictions for their long-term status in the country as well as their working and living conditions. In previous decades, foreign domestic workers were mainly white Europeans who "suffered class subordination and middle-class paternalism but were welcome to Canada as central participants in nation-building and were treated as future 'mothers of the nation"” (Arat-Koc 1999, 215-221). Such was not the case for racialized domestic workers who arrived during the 1960s and onwards-their working and immigration circumstances were extremely oppressive.

Given the racist, sexist nature of immigration and social policies, immigrant women activists like Fatima Filippi began to demand specific improvements to these policies. While Anglo-Canadians continued to work in immigrant support services, over these decades immigrant women began to unite together to assert the need for services for themselves and for other female immigrants. These immigrant women activists, often racialized, asserted that they were best placed to help other immigrants from similar cultural and religious backgrounds and organized to provide much needed culturally appropriate services that had not previously existed. Many of these activists were feminists. Many came to Canada as feminists while others became active as feminists here. Other immigrant activists who did not identify as feminist (sometimes because of the Western connotations of the term), came with social justice perspectives developed in their countries of origin.

During this era there was a plethora of new services founded by immigrant women activists, including English language classes as well as other services intended to help immigrant women fit into Canadian society. In some ways these services were not that different from those offered to new immigrants in the 1950 s and earlier decades. In other ways they were quite different in that even basic programs like English-language classes were much more shaped by activist efforts to determine the needs and interests of the immigrant women themselves. ${ }^{6}$ The services and advocacy provided by most of these organizations were also shaped by the issues of gender inequality and gender oppression raised by the broader feminist movement, such as the need for paid employment for 
women, raising awareness and finding solutions to violence against women, and struggles for reproductive rights. At the same time, despite providing services and advocacy related to these issues, immigrant activists had quite different analyses of these issues, and of the solutions needed to solve them.

A range of feminist and anti-racist scholars have looked at certain elements of the conflicts between immigrant and racialized women and other feminists. These scholars have both identified and analyzed the inability of most white feminists at this time to recognize intersectionality, that other factors besides gender — such as racialization, class, immigrant status and sexuality — are intertwined with gender in the way they impact women's lives (see Agnew 1993; Dua and Robertson 1999; Razack, Smith, and Thobani 2010). They have identified, from early in this period, the differences in the concerns and socio-economic realities between many immigrant women and white feminists. The Leila Khalid Collective, a militant group formed in Toronto in 1970 to integrate women's liberation with those of colonized peoples around the globe, understood the complexity of multiple oppressions: "Women with little time, little education, with families and jobs, or women who have to fight hard to survive on welfare aren't interested in coming to weekly meetings to talk about sexuality and to read Engels" (Leila Khalid Collective in Agnew 1993).

There has been significant scholarly work by racialized and immigrant women on intersectionality. However, few works in the Canadian context have looked at the extent to which questions of family and motherhood might have been understood differently by white Canadian feminists and immigrant women activists, and the way these differences may have helped to shape different responses to and strategies around issues such as paid work, violence against women, and reproductive rights. ${ }^{7}$ Some scholars have explored these questions in the American context, but while we have been influenced by this work, the Canadian context was different in a number of ways, including the distinct nature of Québec, and the far greater levels of immigration to Canada in the 1970s and 1980s as compared to the United States. ${ }^{8}$
Toronto was a major receiving centre for immigrants between the 1960s and the 1980s, with many immigrants coming from Italy, Portugal, Central and South America, the Caribbean, China, and South Asia. As a result, many organizations emerged to serve immigrant women, particularly in the 1970s and 80s. Organizations that were founded in Toronto between 1969 and 1979 included: the YWCA Multi-Ethnic Women's Program, West End Assistance Program, the Centre for Spanish Speaking People, the Cleaners Action Group, Women Working with Immigrant Women, Women's Community Employment Centre, Cross Cultural Communication Centre, Immigrant Women's Centre, Centro Femminile, Immigrant Women's Job Placement Centre, YWCA West Indian Women's Program, and the Working Skills Centre. In the following six years the number of agencies serving immigrants doubled again in the Toronto area (Das Gupta 1986; 1999). While levels of immigration to Vancouver were not quite as dramatic, the city also saw a relatively large number of new immigrants over these decades, particularly from the Philippines, China, and South Asia, and some important immigrant women's agencies and organizations were founded, including the Pacific Immigrant Resource Society, the India Mahila Association, the Philippine Women Centre of BC, and the Vancouver Society of Immigrant and Visible Minority Women. Fewer immigrants came to Victoria in this period, but the city did witness the creation of immigrant support organizations in both Victoria and nearby Duncan, organized by local immigrant women activists.

Immigrant women who came to Canada over these decades faced a range of challenges. For some, who came speaking English or French, with some financial resources and with professional credentials that were recognized in Canada, the situation was somewhat less challenging. European immigrants from Portugal and Italy may have faced somewhat less racism than other immigrant groups, but poverty, language difficulties, immigrant status, and being racialized as "not quite white" still meant that they faced serious barriers. For the many racialized immigrants who came to Canada in this period, the racism of Canadian society posed major difficulties. All married immigrant women faced additional legal problems, particularly in the 1970 s 
and early 1980s, when as noted above, the sponsorship programs limited sponsored women's access to Canadian social programs. The "head of household" (the husband) had access to extensive government funded English as Second Language (ESL) training, but his sponsored "dependents" did not. Sponsored married women also faced the possibility of deportation if the couple separated. We realize that the situation of women from different immigrant groups (and within immigrant groups) cannot be homogenized and that diversity of culture, religion, and class was (and is) very real. While recognizing significant differences among immigrant women, we will also be focusing in this article on certain similarities, similarities that were identified by immigrant women activists.

There are many reasons why motherhood and family were crucial issues in immigrant women's politics. Multiculturalism policies reduced race and racism to cultural differences, defining immigrant families as a hearth to nurture and preserve linguistic and cultural traditions. Immigration laws defined most immigrant women as dependent wives and mothers. New welfare state policies often excluded immigrant women, thus making them even more economically dependent upon their male spouses. Together these multiculturalism, immigration, and welfare state policies encouraged both new immigrants and others to view immigrant women as economically dependent mothers whose main goal was to maintain and preserve the culturally distinctive family. To cement immigrant women's relationship to their families further, the family was often a bulwark in a racist society, a place where immigrant women, men, and children found shelter from a profoundly racist society. Thus, it is not surprising that immigrant women activists tended to shape their political issues around the familial and maternal needs of immigrant women. This did not mean that they were uncritical of the patriarchal oppression faced by many immigrant women-but it meant that they had a far greater recognition of the need to be sensitive to issues of family and motherhood than other feminists. Below we explore three key issues in immigrant women's activism: paid work, violence against women, and reproductive choice. While these were political issues that immigrant women and other feminist activists shared, the former shaped these issues differently, in a manner that recognized and appreciated immigrant women's family demands and political realities.

\section{Paid Work}

Both immigrant women activists and other feminists were deeply concerned about paid work issues during this era. Paid work was an economic necessity for most immigrant women and their families. Even if poorly paid, working in exploitative conditions, immigrant women were critical wage earners to help ensure family survival in the new country. Consequently, employment was a central issue for immigrant women's politics. But immigrant women and white liberal and socialist feminists tended to approach employment issues differently. Whereas white liberal and socialist feminists were focused on pay equity, childcare, unionization, and paid work that led to economic independence from men, immigrant women activists tended to organize around employment issues that were shaped by family responsibilities. For most immigrant women, paid work was a necessity but it was also critical that this paid work complement unpaid caring work at home. Many immigrant women were life-long workers but had interruptions in this paid work due to family issues such as pregnancy, childcare, illness, or a husband's employment constraints. Consequently, our archival and interview data show that immigrant women activists prioritized the following employment issues: employment equity, workplace health, ESL training, accreditation, foreign domestic workers' rights, and in some cases, unionization.

While the wages they brought in were essential, most immigrant women needed their paid work to be secondary to their work in the home. As a result, many immigrant women worked as night-time office cleaners, home-based garment workers, or other paid work that allowed them to care for their children and prepare the meals for their families. "Janitorial cleaning was a good job for immigrant women because it's at night. And so, they would be with the kids all day, the husband got home from construction work, and the woman would leave for her job, so that someone was always there with the kids.... But they maintained the primary responsibility for household labour," explains Susan Miranda (2016), who both researched and ad- 
vocated for Portuguese immigrant women in Toronto. A 1979 article in Kinesis noted that immigrant women were choosing to do industrial sewing at home, even though it was very exploitative, with low wages, so that they could remain at home with their children (17).

As wife and mother, immigrant women played a central role between the home and a racist society. They witnessed the male head of the household having little economic or social power in the broader society and they watched their children, who were often more fluent in English and the new country's values, challenge their father. While there were still unequal power dynamics at work in the immigrant woman's household, she often took pride in her position as the primary educator of cultural and religious values - as the person who sheltered her husband and children from the alienation they experienced outside the door. "It was always about the kids first," explained Hortensia Houle, who helped run the Cowichan Valley Intercultural and Immigrant Society, north of Victoria, BC. "We never neglect the children. For us, the main goal wasn't to be employed but how we can raise our children...how we can be part of this community" (Houle 2016).

Scholars have echoed these arguments, noting that for various immigrant groups in this period, women's role in the home was considered crucial for keeping the family together. ${ }^{9}$ This has been discussed in relation to a range of different immigrant groups (Agnew 1996, 2000; Ng and Ramirez 1982). A study of Uruguayan immigrants in this period noted: "Motherhood is generally regarded as the ideal state for a woman. She may take a paid job, but if her family demands her presence at home there is no argument: her first obligation is to them" (Alberro and Montero 1976, 131-148). And Sunera Thobani suggests that some immigrant women would have gained status and power within their families and communities as the promoters and preservers of culture and language $(2007,167)$.

This primacy of family and home created tensions between immigrant women activists and other feminists. Judith Ramirez, a member of Toronto Wages for Housework, an international socialist feminist organization that advocated wages for homemakers, remem- bers strains between immigrant women activists and other white feminist leaders. "In that period most of it was not only disagreement, it was virulent disagreement.... All the emphasis [from other feminists] was about women working outside the home. Anything about women in the home was almost by definition seen as retrograde" (Ramirez 2016). Meanwhile many immigrant women found the home and family a sanctuary from a racist and alienating society. As Ramirez explains, "The immigrant women had to think about the harmony within their families, and their children succeeding at school and any paid work had to work around what was happening in the home." "Motherhood is very important for most of the immigrant families," explains Tomoko Okada who was coordinator of the Immigrant and Refugee Settlement Program in Victoria. "They start thinking about children's education, they move to Canada, so the children's well-being was the most important priority issue for immigrant parents" (Okada 2016).

Immigrant women demanded the right to stay at home with their children, if that was economically feasible. Hortensia Houle challenged the women's movement's opposition to stay-at-home motherhood, which was seen as preventing women from gaining independence, arguing:

Isn't it better for us to support her while she nurtures her children for three, four, five years until they're in full-time school, and then send her to a job? I'm not saying I advocate women to stay on welfare all their life but you have to think about the timing. For a mom to leave her young child in daycare to go work at a minimum wage job, come home, have the same amount of money that she would get on welfare but is extremely tired...isn't it better for us that she spends that time with her children if that's what she wants? (Houle 2016)

And Ramirez explains, "They [immigrant women] wanted to say, look what we're doing is respectable. Don't treat us like second class citizens of the sisterhood" (Ramirez 2016).

Immigrant women's groups were less focused on women's economic independence from men through well-paid jobs. "We weren't focussed on equal pay," ex- 
plained Victoria organizer Amarjit Bhalia, "Our organization was about giving value to women, of making sure women have the chance to excel, just as men. [Both immigrant women activists and other feminists] wanted to value women but we did it in different ways" (Bhalia 2016). Ramirez who was advocating for immigrant domestic workers in Toronto agrees with Bhalia. "There was no opposition to equal pay. It wasn't about divisions in that sense. It was more about focussing on the immediate needs and what's most urgent in your life" (Ramirez 2016). Rather than pay equity, immigrant women activists interviewed about paid work spoke about their desire for homemaker pensions, increased welfare rates and services that recognized the very busy lives and multiple responsibilities of immigrant women. Some of these policies would allow women to do less paid work, not more. As one immigrant woman activist recalls with a chuckle, "I never got the white girls' focus on the right to work. Work?! We [immigrant women] had work. We wanted less work" (Interviewee O-3 2017).

Instead of pay equity, immigrant activists were more interested in employment equity, legislation to increase the representation of not just women, but people with disabilities, Indigenous peoples and racialized peoples, both women and men. As Debbie Douglas explains,

We knew that race was so central to a lot of the discrimination that we were facing. And the men in our lives were facing. So as Black feminists we organized around women's equity but we also had to organize around our communities. And our communities tended to be our families.... So Black men's realities were important to the work that we were doing in terms of the kind of societies we were wanting to build. (Douglas 2017)

Therefore, even when immigrant women activists and other feminists were talking about employment issues it was different employment policy, with different goals.

Because of the distinct nature of immigrant women's work, child care was framed differently amongst immigrant women activists. Publicly-funded, affordable, high-quality childcare was often a central demand of white socialist and liberal feminist groups during this era. They saw childcare as key to women entering the paid workforce (Pasolli 2015). Immigrant communities, on the other hand, were more mixed about child care issues. Daycare did not work for those immigrant women who worked nights and were at home with their children during the day. Other immigrant women preferred to stay home and raise their children, if economically possible, ensuring that their children had cultural and linguistic skills from their home country. Or, if not, they had extended family members provide care, or sponsored their parents to come to Canada as a way to provide informal at-home care for their children. "The practical realities of life often meant that many of the immigrant women would take care of these things within the family. You know, parents or aunts and uncles, because you have to solve the problem. You can't wait for big policy changes to get to the factory the next morning," explains Ramirez (2016). Some immigrant women also opposed the racist attitudes they experienced at child care centres. Miranda recalls, "the daycare sometimes brought in speakers to say, 'This is how you should raise your child'... They told [immigrant] mothers they can't spank their kids... The women didn't like it that much so there definitely were tensions with daycare centres" (Miranda 2016).

Whereas immigrant women activists were careful in how they advocated around public childcare, many of them strongly advocated for workplace health. Ramirez recalls the importance of the mobile health clinic van that parked outside the factories where the immigrant women worked.

When we set up the immigrant women's centre the first thing we addressed was the fact that these women had a double work shift. Many of them were working outside the home at factories, and then they were coming home to the responsibilities of the family. Their children were in school. Their husbands came home tired. They had to cook and clean. So, what do we do? We set up a mobile health clinic, the van comes to the factory. We negotiate with the employer, you give them a half hour off during lunch and they come in, they see the doctor, the nurse. (Ramirez 2016)

The politics of the mobile health clinic makes clear 
that immigrant women activists understood that health care and any other immigrant woman's issue had to be shaped around their family and work lives (Das Gupta 1986, 54-56). Through this concern about health emerged a number of immigrant health centres (Das Gupta 1986).

Immigrant women activists realized that their clients wanted ESL training for a variety of reasons. Government-funded ESL was provided for immigrant men but not for immigrant women, if they were dependents of their husbands. Immigrant women wanted these skills. In some cases, they wanted ESL to get or keep their jobs or to get better paid jobs. Deb Barndt (2016) who worked with Latin American immigrant women and was known for her Freire-inspired community participatory work, remembers offering ESL classes at the factories. "We would teach English to workers in their workplaces so we met with them after work in the cafeteria." Barndt was a photographer so they created photo stories to learn ESL: "There were stories of just trying to get through the transit system but as a metaphor for how you survive in a new context and also how to... [negotiate] your first job interview." Out of this emerged ESL survival kits, songs, radio soap operas, videos, books — all used as teaching and political organizing tools. "These women were seeing themselves in these materials and that their lives mattered and it gave them dignity," Barndt explains. Through these community-participatory educational projects emerged the Women Working with Immigrant Women coalition and the Working Women Centre (Barndt 2016; Marino and Barndt 1983).

Immigrant women who were staying home also wanted ESL because they wanted to be able to advocate for their children in the school system. Beverly Nann, who helped found Pacific Immigrant Resources Society in the 1970s, recalls they did a lot of outreach with immigrant mothers and pre-school children. For example, they offered a Head Start program that helped immigrant mothers and their pre-school children, simultaneously, get ESL skills before the children went to school (Nann 2016). Hortensia Houle, former president of the Cowichan Valley Intercultural and Immigrant Society, recalls that she advocated for ESL training for men as well. "We had ESL classes for wo- men but then the [immigrant] men realized that they were relying on their children to translate for them. Some of them weren't learning English in their workplaces and they wanted the same training that their wives were getting." So, although Houle started by providing ESL classes for immigrant women she later applied for government grants to provide the same classes for immigrant men (Houle 2016).

Accreditation was another important employment issue for immigrant women. "We lobbied for years around accreditation," recalls Hortensia Houle. Many immigrant women arrived with post-secondary education and credentials that were not recognized in Canada. Houle helped women get accreditation in the health care sector and in translation. "They already had the skills, they just weren't recognized," she explains. Soon Houle had immigrant men coming to her asking her to advocate for their accreditation as well (Ibid).

An employment issue that was a rallying cry for many immigrant women activists was the plight of foreign domestic workers. This issue exposed the racist and elitist state immigration and employment policies which permitted middle class and predominantly white women to leave their homes for paid work and growing economic independence while relinquishing their caring work to immigrant and predominantly racialized women. Simultaneously, this issue bound caring work and paid employment together. Many immigrant women were brought to Canada on temporary work permits. They were forced to work in Canadian homes doing childcare and housework for many hours and were afraid to complain about their exploitative situations for fear of deportation. They were indentured workers with no mobility rights. Immigrant activists worked with them to try and organize domestic workers' unions in the late 1970s and early 1980s, with limited success. Immigrant organizers fought for these women to be included in employment standards legislation, to limit their hours of work, and to give them the rights of landed immigrants. Makeda Silvera's path-breaking book Silenced (1989) spoke about the struggles of working-class Caribbean immigrant women, many of whom were domestic workers. "Makeda really gave a profile to domestic workers' issues," explains Debbie Douglas. "These women often 
only had Saturday night and Sunday morning off before they had to go back [to work]. And she [Silvera] would meet them at parks or any place where they could gather to talk about their experiences and she captured their stories in the book" (Douglas 2017). Silvera made it very clear that the situation of the domestic workers was the obverse of the mainstream feminist ideal of women's employment. Many of the employers of the exploited domestic workers were professional women, whose independence in the workforce was at the expense of the immigrant women they employed at low wages to care for their children and do the housework. These immigrant domestic workers worked long hours to send their wages home to support their own children, left behind in their homelands (Bakan and Stasiulis 1997).

In 1979 Judith Ramirez played a central role in founding INTERCEDE, a major Toronto-based organization that defended the rights of immigrant domestic workers. Gradually, over the course of the 1980s, INTERCEDE won some victories, including changing the law in 1981, so that after two years of domestic work, these women could apply for landed immigrant status. However, many barriers remained, and INTERCEDE continued over this period to advocate to improve the rights of immigrant domestic workers. This issue was primarily of concern to immigrant activists but a number of high-profile white mainstream feminists also came out in support of immigrant domestic workers, helping to put more pressure on the government to change its racist policies (Agnew 1996, 180191).

For Judith Ramirez, who helped found INTERCEDE, there was a direct connection between the plight of immigrant domestic workers and the international socialist feminist organization called Wages for Housework (WFH), which argued that women's work in the home needed to be valued, and that those doing housework should be paid by the state. "Wages for Housework is an abstract analysis in a certain sense... a focus on the woman in the home. But with INTERCEDE it was very specific to the foreign domestic workers who were coming under these very harsh regulations," explains Ramirez (2017). "It's a very intractable issue, the undervaluing of women's work in the home, and outside the home when they're doing housework like activities for others.... Immigrant women were being locked into double workloads that were so punishing." Ramirez argued that other feminists:

had such a blind spot about the value of women's work that was not in the paid workforce.... We were pushing against that view quite forcefully...I'm sure that if you asked those mainstream feminists they would at least pay lip service to "of course what happens in the home is also important," "raising children is important" etc., etc. But that's not quite the same as actually giving it the kind of weight that is necessary when you're tackling issues and deciding what you're going to fight for. (Ibid.)

Wages for Housework's focus on supporting women's work in the home in fact led to quite a negative reaction from mainstream feminism's umbrella organization, the National Action Committee on the Status of Women (NAC). As other scholars have noted, in 1979 the NAC rejected WFH's application for membership in NAC (Marks et al. 2016; McKeen 1995; Vickers et al. 1993). In justifying this decision NAC President Kay Macpherson explained that while NAC and WFH agreed on short term goals such as childcare, job training, and improved services for women, the two organizations differed tremendously on long term goals. Macpherson wrote:

What NAC is aiming for in the long run -equal opportunities, equal pay and end to sex role stereotyping, appears to be in contradiction to the basic goal of the WFH groups, since the aims of Wages for Housework-pay for housework, even the housework done in keeping oneself clean and fed...ultimately reinforces the stereotype of women in the home. (Marks, Little et al. 2016)

The NAC's refusal to admit WFH led to some pushback even from some white, professional women, who noted that WFH did important work with immigrant women, lesbians, and women on welfare, who NAC did little to support at that time (Ibid.). Certainly, WFH worked closely with immigrant women. In addition to Ramirez's work with INTERCEDE she was 
central in organizing a one-day event with Toronto WFH entitled "A View from the Kitchen: Immigrant Women Speak Out on the Value of Housework." WFH newsletters argued that immigrant mothers often "carry the heaviest burden," are "denied a basic sense of accomplishment for [their] role in the home," and are then further exploited through low paid domestic work (Wages For Housework 1979).

WFH also played an important role in supporting immigrant workers in Vancouver. Under the leadership of WFH activist Ellen Woodsworth they allied with South Asian and Japanese Canadian women's groups, and together organized activist Mothers' Day events in East Vancouver in the early 1980s. These events celebrated the value of mothers' unpaid work, as well as recognizing the particular forms of oppression facing immigrant women, women on welfare, and lesbian mothers. ${ }^{10}$ In 1980, the Mother's Day event highlighted the oppression of immigrant domestic workers, while a speaker from the South Asian Indian Mahila Association talked about the many burdens immigrant women face: they suffer all the handicaps that white women suffer in Canada, and moreover, they face racism and have to fight back against domination and exploitation by the men within their own community (Kinesis 1980, 3).

Finally, unionization was a complex employment issue for many immigrant women. It was often difficult for immigrant women to organize into unions because of their poverty, their lack of adequate English, their focus on their homes and families, and their extremely long double days, both in the workforce and looking after their families. In the 1970s this sometimes meant that feminist trade union women ignored immigrant women in workplaces since they felt that these women did not take advantage of available opportunities. As a result, some immigrant activists organized immigrant women separately from feminist trade union women or the mainstream labour movement. Some efforts to encourage unionization were successful. Miranda recalls that immigrant women activists went to downtown buildings at night and handed out leaflets to the immigrant women cleaners, to help them understand their collective agreements and their rights as workers. They founded the Cleaners' Action Program to sup- port these women and their jobs as companies started contracting out the cleaning. Community centres in the downtown Kensington Market area of Toronto became quite political as the Cleaners' Action Program and politicized English as Second Language classes were held there (Das Gupta 1986, 20; Miranda 2016). Immigrant women activists helped support immigrant women cleaners when they refused to work because they were given dirty or malfunctioning equipment (Interviewee O-2 2017). Miranda believes that the highlight of the Cleaners' Action Program was the protest in 1985 at First Canadian Place in downtown Toronto on Bay Street when 250 women, mainly immigrants, were on strike (Miranda 2016). This was a pivotal moment of immigrant women's politics: "They were on the picket line for six weeks.... It was a very grassroots kind of movement...but I think [it] definitely contributed to an immigrant women's movement that kind of paralleled the formal women's movement" (Ibid.). Another important political moment for immigrant women was a general strike of garment factory workers that shut down Spadina Avenue. As one activist recalls, "It was a massive strike for working conditions for that sector. It was an all-day, day-long strike; it was really exciting because there were immigrant women taking to the streets and fighting back and saying "We demand our rights'" (Interviewee O-2 2017).

Many immigrant women activists dedicated their political lives to employment issues. But because of state policies that enforced immigrant women's economic dependence upon their spouses, immigrant women needed to shape their employment around the needs of their families. Thus, immigrant women's political issues around employment were also affected by these familial demands. Consequently, employment equity, workplace health, ESL training, accreditation, and domestic workers' rights were key issues for immigrant women's employment activism. Sometimes this politics took place on the union shop floor but more often, these politics played out in places that were not traditionally considered political sites, such as immigrant women's homes, in mobile health clinic vans, and in immigrant service and community centres. 


\section{Violence against women}

Immigrant women activists and other feminists were both concerned about violence against women but they approached the issue quite differently. Whereas white liberal and socialist feminists tended to understand violence against women as rooted in male power and privilege, immigrant women activists nuanced this analysis to appreciate how racist state policies and police impacted both immigrant men and women. As a result, immigrant women activists saw the home as both a source of violence and also a haven from the racist violence of a hostile new land. In some cases, immigrant women activists and other feminists came together as they lobbied and staffed women's shelters. But shelters were both a site of collaborative politics and a site of racism. Vijay Agnew in her important book, In Search of a Safe Place (1998) has explained the challenges for racialized women when they engaged with women's shelters. She explains how social service agencies, including women's shelters,

have 'monocultural models' of delivering services, that European and North American cultural values and norms influence the way service providers define the problems of abused women and the solutions they offer. They often alienate women with vastly different cultural values, and the women withdraw from seeking services from these agencies. (Agnew 1998, 9)

The immigrant women activists interviewed for this research project agreed with Agnew's assessment of the challenges facing abused immigrant women at women's shelters. One immigrant woman activist who had worked at women's shelters explained the struggles within the shelter movement:

We were all working in the shelters and we were all young and gung-ho, going to bring a progressive feminist politics (what today we would call an intersectional feminism) to [the shelter] collectives but many of the women were entrenched in their own ways and wanted you to just come in and work relief and shut up. They were not into power sharing. (Interviewee O-1 2017)

Agnew argues that most women's shelters often neg- lected the social, economic and political context in which violence is perpetrated, focusing instead on gender relations (Agnew 1998, 164). As Amarjit Bhalia, who was involved in the Indo Canadian Association in BC explained, some women, who were defined as dependents by the immigration laws, risked deportation if they admitted to abuse. "These women who didn't speak the language were terrified, thought they were going to be sent home." Because of the difficulties accessing women's shelters, Bhalia met abused immigrant women in their homes (2016).

Racism was also an issue that was not recognized in many of the shelters. Kay Blair from Jamaica left her abusive husband and went to a shelter in Toronto. However, at the shelter she had a "devastating" experience, in which the shelter workers reinforced racist ideas about Black men being particularly violent, and "stereotypes about Black women and the acceptance of violence" (Lior, 2012, 58). This experience was not unique to Blair, as immigrant women often faced racism at women's shelters, as well as comments regarding stereotypes of immigrant men being particularly likely to be abusers and immigrant women acting as passive victims (Agnew 1996). What shelter staff did not appreciate is how state policies (especially immigration and multicultural policies) helped produce this particular racist understanding of the immigrant family. Immigration laws ensured the male was the economic head of the family (Thobani 2007, 131). Multicultural policies that encouraged the celebration and conservation of cultures encouraged the belief that immigrant families were culturally backward and impervious to change (Ahmed 2000, 95-113; Thobani 2007 (esp. chapter 4)). These state policies shaped immigrant families, increasing the power of male heads of households and diminishing the power of women. Yet, shelter staff assigned full blame to immigrant men rather than acknowledging the role of the state and saw immigrant women as helpless victims of this hypermasculine domination.

As well as dealing with racism, non-Christian women often found a lack of sensitivity to religious and cultural traditions, as well as language issues in many women's shelters (Marks, Little et al. (n.d.)). Shelter staff associated immigrant cultures with oppressive values 
and were ignorant of their own internalized cultural norms. They were quick to dismiss any cultural traditions other than their own and they did not recognize the depth of the barriers created for immigrants who did not speak English.

The racism and cultural and language barriers experienced in women's shelters prompted a group of immigrant and racialized women's shelter activists to found Shirley Samaroo House in the early 1980s, the first shelter in Toronto specifically catering to abused immigrant and racialized women. The shelter was named Shirley Samaroo after a Black woman who left a shelter and was subsequently killed by her husband (Agnew 1998, 100). At Samaroo House, the staff addressed racism when it occurred at the shelter. As one of Agnew's interviewees stated, "At Shirley Samaroo House we could not [overlook] racism-as some other shelters [might] gloss over it.... We would make it an occasion for conflict mediation or conflict resolution" (Agnew 1998, 138). The shelter collective was clear that they needed to do public education that reached far into immigrant communities. "I think we were probably one of the very few shelters who saw public education and policy as part and parcel of the work that we did.... It wasn't only about counselling and women's right to leave and all of that" (Douglas 2017). That's why Samaroo House staff went out into the immigrant communities, gave public talks about violence against women, left brochures in community and religious centres, and spent time meeting with community and religious leaders.

Other immigrant women activists explained how they would connect violence issues with other pertinent issues facing immigrant women. Fatima Filippi, another immigrant woman activist, recalls how "we would bring all the needs together, offer a variety of services. We had a Wen-do self-defense course for women.... We did counselling. We did English classes. We did rights and advocacy. It was a hodgepodge of everything" (Filippi 2016).

As part of this integral approach to violence against women, immigrant women activists learned to include men in the solution. At the request of immigrant women clients, these activists created men's groups and individual counselling sessions for men. "It challenged our own biases and how we worked with immigrant women.... Here we were victimizing the women again [by deciding what services they needed and wanted]. We had to think about empowerment and how we create opportunities for empowerment, and recognizing that women do have power but helping them to address it, and to find it and to use it [in their own way]," explains Filippi (2016). Similarly, across the country, Hortensia Houle recalls creating men's groups to discuss violence at the Cowichan Valley Intercultural and Immigrant Society (Houle 2016). And so, over time these immigrant women's organizations offered services to men. They also incorporated violence against women into their other services. "It's a paradigm shift.... If we did English classes that included men, we did violence education in that group, you know, we have International Women's Day and we invited men, we talked about violence against women, about women's empowerment" (Filippi 2016).

While immigrant women activists did support women's independence, they also respected women's choices to remain or return to abusive men. They understood that racist state policies created greater economic dependency for immigrant women and explained the repeated use of shelters as necessary for immigrant women's economic survival. Tomoko Okada noted that, as a member of Immigrant and Visible Minority Women BC:

We had a joint conference with the transition house group, who helped abused women...we felt, for abused immigrant women, when they go to transition house, the shelter, it's not the appropriate service for immigrant women, because at transition house, many workers are kind of pro-women's movement advocates. So, they really actually focus on immigrant women to become independent, and just leave the husband. But most of the immigrant women, they just want to improve the home situation, to change the husband's attitude. So, I think, this is an...issue about transition house, just force the woman to leave the husband. (Okada 2016)

In many cases, the husband provided the majority of the family income and immigration laws ensured that 
they, as immigrant women, may have been denied the English language skills to find a well-paid job to provide economic independence for themselves and their children. Also, immigration policies meant many immigrant women were sponsored by their husbands to immigrate to Canada and thus feared deportation if they left their abusive husbands.

Immigrant women activists also learned to frame the issue of violence in a way that incorporated an understanding of a violent state. Two of the immigrant women activists interviewed said their violence agenda needed to shift to include police violence. Black immigrant mothers desperately wanted to talk about and to organize against the police violence that their brothers, partners, and sons experienced (Douglas 2017; Kohli 2016). "There was violence against women and violence against young Black males because of police brutality. We couldn't look at one and not the other," explained Rita Kohli, who was involved in immigrant women's and shelter politics. She explained that they needed to extend the politics of violence to address migration, crossing borders, carding, and other violence and harassment that Black immigrant women and their families experienced daily (Kohli 2016).

Some of the immigrant women activists said other feminists who worked on violence against women issues, focusing exclusively on gender oppression, did not appreciate their more broadly political and familycentred approach to violence. "We took a lot of grief for that, let me tell you. We were perceived as antifeminist.... We just stuck by what was right for our clients" (Filippi 2016). Immigrant women activists appreciated that violence against women issues needed to be situated within an understanding of racist immigration and multicultural policies that reinforced immigrant women's economic dependence upon men. They also understood that they could not address domestic violence and ignore all the other types of violence that occurred in subtle and aggressive forms when immigrant women and their families interacted with employers, landlords, welfare administrators, and the police.

\section{Reproductive Justice}

Reproductive justice was another issue that differed in how it was shaped by immigrant women activists. During this era there were many pro-choice marches and rallies. Feminists would come out in huge numbers to chant "Not the church. Not the state. Women must control their fate." But although many feminists argued for reproductive choice they could be unaware of the complexity of choice for immigrant women. For many immigrant women, state policies and cultural traditions situated discussions of a woman's rights to control her body within the context of family and community. One immigrant woman activist recalls differences between immigrant women activists and other feminists over reproduction:

There were some interesting tensions around the Morgentaler Clinic. I think a lot of it was a mainstream approach versus understanding how cultural communities would react to those things...some of these were Catholic cultural communities who were opposed to abortion... So yeah, there were some major tensions. (Interviewee O-2 2017)

For some of the immigrant women activists, they learned to keep their reproduction politics separate from their work with their immigrant female clients. As one activist explained, "I would go to the marches for the Morgentaler Clinic and was there when there was a huge protest and all of that, but that's what I did with my mainstream relationships. I would never bring that issue to my [immigrant] communities because there wouldn't be support for it" (Ibid.). And Ramirez who advocated for domestic workers explained, "The realities of life are such that people support things that they need, even if they're not ready to advocate publicly for them, much less to fight in a march or be in a delegation to meet a politician who's able to change the law" (Ramirez 2017). Working with immigrant women, Debbie Douglas recalls supporting young women, some of whom were pregnant. "We were trying to empower the women.... And so, we wanted to just support them through the process and giving them the message that, your life doesn't end here at 17 because you have a child. And so, we were really fighting the system.... We wanted them to have choice-real 
choice. [Not the feminist] choice which meant you had to have an abortion" (Douglas 2017).

In 1977 the Immigrant Women's Centre in Toronto declined an invitation to join the Coalition for Abortion Rights. The Centre stated:

Many of us, both immigrant and native born, are forced to have abortions because we cannot afford to have the children we want. Immigrant women have always experienced coercion either by being forced to have children (by denying us birth control and abortion) or by being prevented from having children (through genocidal birth control practices in the Third World as well as against Black women in the USA and Native Peoples in Canada). For us, the "right to choose" can never be only the right to abortion, but must also be the right to have all the children we want. (Immigrant Women's Centre 1977)

They were painfully aware that immigrant and racialized women often were prevented from mothering by a racist state. At the same time, they certainly wanted the right to choose when and whether to have children. They demanded free abortion on demand, and free and safe birth control, noting: "We want services that recognize that immigrant women often refuse contraception because our experiences have taught us to be suspicious of the methods available, and not because we are "backward." In order to be able to choose freely (whether or not to have children) they also demanded living wages, fully paid maternity leave without loss of seniority, and funding for 24-hour childcare "controlled by us with paid staff both in our neighbourhoods and in every sweatshop where we are forced to work" (Ibid).

Reproductive rights also had implications for the transnational lives of immigrant women activists. Immigrant domestic workers who were denied the ability to bring their children into Canada focussed on family reunification issues rather than abortion rights. These women wanted the right to reproduce, the right to live with and care for their children and they were very aware of how Canadian immigration and labour policies limited their reproductive freedoms.
What immigrant women activists learned, time and again, is that there was not one clear position on reproductive issues. Individual immigrant women activists made personal alliances with mainstream feminists but they often could not bring this politics into the immigrant communities they served. And reproductive rights could look very different for women who valued motherhood and had often faced a state, either in Canada or abroad, that used its power both to deny women the right to have children, and the right to live with and care for their children.

\section{Conclusion}

As we have seen, issues related to family and motherhood could create major tensions between immigrant women's activists and other feminists, and at times between immigrant women and immigrant women activists. Canadian state policies such as immigration, multiculturalism, labour, and welfare policies reinforced immigrant women's economic dependence upon the family. Thus, immigrant women's politics were shaped by their familial and maternal responsibilities. While many immigrant women were life-long paid workers, their working careers were often distinct from their male partners and from other feminists. Sometimes their working hours were at night so they could juggle family responsibilities during the day. Sometimes they took several years off paid work when their children were young, because this was important to them, in part so they could teach their children linguistic and cultural values that were central to their family. Sometimes their children were in their home country while they toiled in a Canadian family's home, caring for someone else's children. As a result, immigrant women's politics were shaped by their everyday lives. While they were often concerned about some of the same issues as other feminists-paid work, violence against women and reproductive rights-we see how they shaped these issues around motherhood and family concerns. In regards to labour, they demanded access to job training, English language classes, healthcare on the job, and employment equity for racialized women and men. When it came to violence against women they demanded shelters, as did other feminists, but they exposed the racism they experienced in feminist shelters and began to build shelters specifically for 
immigrant and racialized women. They also demanded domestic violence programs that included men. And they expanded their politics of violence to protest against racialized police violence. In regard to reproductive justice, immigrant women had different perspectives, but all supported their right to have children and to care for their own children. Thus, they embodied a politics that acknowledged and challenged the racism they faced, respected religious and cultural values, and acknowledged the fact that the heterosexual family remained an important resource for the majority of immigrant women.

Immigrant women had many different experiences and perspectives in Canada. But they all wanted more rights and more prosperous lives free of racism and inequality. They also knew that their everyday lives were deeply enmeshed with the needs of their families. They were conscious of the many racist state policies that made them economically dependent upon their families. And similarly, they were aware of how their families provided support and cultural continuity in a racist society.

\section{Notes}

We would like to thank Franca Iacovetta and the anonymous reviewers for their very helpful comments on this article.

For the interviews we conducted, some women wished to be anonymous, so are listed as $\mathrm{O}-1, \mathrm{O}-2$, etc.

\section{Endnotes}

1. "Alternative Visions: The Politics of Motherhood and Family among Indigenous, Immigrant, Racialized and Low-Income Activist Women's Groups in Canada, 1960s-1980s," SSHRC Insight Grant, 2018-2023. Margaret Little, Lynne Marks, and Sarah Nickel.

2. We use the term "mainstream feminists" cautiously. We are aware that many of these women would not define themselves or their activism as mainstream. Yet, more recent scholarship has defined the work of liberal and socialist feminists of this era who challenged but did engage with the state as "mainstream feminists."

3. There are many more we could name but these are the Canadian critical race scholars who have left the biggest imprint on our understanding of race and racism.

4. We are aware of the slipperiness of the term "second wave feminism" and the imprecision with which it attempts to demarcate women's activism during the 1960 s to 1980 s in the global North. At the same time, from this preliminary archival and interview data it is clear that there are distinctions that need to be made between the women's activism that has been previous detailed in feminist politics texts and the activism of women who were advocating for less privileged women (Sandoval 2013, 41-42).

5. There are some publications produced by members of the immigrant activist community about immigrant women and organizing in the 1970s and 1980s. See, for example, Lior (2012) and Das Gupta (1986).

6. See, for example, Dian Marino and Deborah Barndt, Immigrants Speak Out (1983), which includes booklets immigrant women created to practice their English. In these booklets, women wrote stories and songs about their everyday lives, such as their work in textile factories.

7. Earlier work that does deal with motherhood and family among immigrant women in relation to some of these issues includes Roxanna $\mathrm{Ng}$ and Judith Ramirez (1982) and Agnew (1996). There are also differences between immigrant and mainstream feminists related to questions of religion, which we have explored elsewhere (Marks and Little et al. n.d.).

8. For American work on questions of difference related to motherhood and family between mainstream and immigrant and/or racialized women see, for example, Roth (2004), Baxandall (2001), Nadasen (2002), Thompson (2002), and Garcia (1989). For one Canadian work that addresses some of these issues see Billson (1995). Amanda Ricci (2015) has explored both immigrant and mainstream women's groups in 
Montreal, but motherhood was not a central focus of her work.

9. This argument has been found in a number of important works. Angela Y. Davis begins with the crucial role Black women played in their Black families during slavery and discusses this legacy. Patricia Hill Collins in the US and Valerie Amos and Parmar Pratibha in the UK explore how women of colour find refuge and take on leadership roles within their families. See: Davis (1981) Chapter 1; Hill Collins (2000) esp. 50-51; and Amos and Parmar (1984).

10. By 1982 a range of these organizations had affiliated with the organization 'Women Workers in the Home,' a 'group of women and organizations concerned about the status of women in the home.' It seemed to have been organized primarily by local WFH activists. Kinesis (1982, 12-15); Kinesis (1982, 14-15); Kinesis (1980, 3). Also see interview with Ellen Woodsworth (2016).

\section{References}

Abu-Laban, Yasmeen. 1998. "Keeping 'em out: Gender, Race, and Class Biases in Canadian Immigration Policy." In Painting the Maple: Essays on Race, Gender, and the Construction of Canada, edited by Veronica Jane Strong-Boag, Sherrill E. Grace, Joan Anderson, Avigail Eisenberg, 69-82. Vancouver: UBC Press.

Agnew, Vijay. 1993. "Canadian Feminism and Women of Color." In Women's Studies International Forum 16, no. 3: 217-227. https://doi.org/10.1016/02775395(93)90052-B.

1996. Resisting Discrimination: Women from Asia, Africa, and the Caribbean and the Women's Movement in Canada. Toronto: University of Toronto Press.

1998. In Search of a Safe Place: Abused Women and Culturally Sensitive Services. Toronto: University of Toronto.

Ahmed, Sara. 2000. Strange Encounters: Embodied Others in Post-Coloniality. London: Routledge.

Alberro, Ana, and Gloria Montero. 1976. "The Immigrant Women.” In Women in the Canadian Mosaic, edited by Gwen Matheson, 131-148.

Toronto: P. Martin Associates.

Amos, Valeria, and Parmar Pratibha. 1984.

"Challenging Imperial Feminism." Feminist Review, no. 17: 3-20.

Arat-Koc, Sedef. 1999. "NAC's Response to the Immigration Legislative Review Report: 'Not Just Numbers...." Canadian Woman Studies 19, no. 3: 1823.

Bakan, Abigail B., and Daiva Stasiulis, eds. 1997. Not One of the Family: Foreign Domestic Workers in Canada. Toronto: University of Toronto Press.

Barndt, Deb. Interview March 22, 2016. 
Baxandall, Rosalyn. 2001. "Revisioning the Women's Liberation Movement's Narrative: Early Second Wave African American Feminists." Feminist Studies 27, no 1: 225-245.

Bhalia, Amarjit. Interview July 27, 2016.

Billson, Janet Mancini. 1995. Keepers of the Culture: The Power of Tradition in Women's Lives. Virginia: Lexington Books.

Dahmoon, Rita, 2009. Identity/Difference Politics: How Difference is Produced and Why it Matters. Vancouver: University of British Columbia Press.

Das Gupta, Tania. 1986. Learning from Our History: Community Development by Immigrant Women in Ontario, 1958-86. Toronto: Cross Cultural Communication Centre. 1999.”The Politics of Multiculturalism: 'Immigrant Women' and the Canadian State." In Scratching the Surface: Canadian, Anti-Racist, Feminist Thought, edited by Enakshi Dua and Angela Robertson, 187-206. Toronto: Canadian Scholars' Press.

\section{7. "Immigrant Women's Activism: The}

Last Thirty Years.” In Race, Racialization, and Antiracism in Canada and Beyond, edited by Genevieve Fuji Johnson and Randy Enomoto, 105-116. Toronto: University of Toronto Press.

Davis, Angela. 1981. Women, Race and Class. New York: Random House.

Douglas, Debbie. Interview 2017.

Dua, Enakshi, and Angela Robertson, eds. 1999. Scratching the Surface: Canadian, Anti-Racist, Feminist Thought. Toronto: Canadian Scholars' Press.

Epp, Marlene and Franca Iacovetta, eds. 2016. Sisters and Strangers: Immigrant, Ethnic and Racialized Women in Canadian History. Toronto: University of Toronto Press.
Garcia, Alma M. 1989. "The Development of Chicana Feminist Discourse, 1970-1980." Gender and Society 3, no. 2.

Filippi, Fatima. Interview 2016.

Garcia, Alma M. 1989. "The Development of Chicana Feminist Discourse, 1970-1980." Gender and Society 3, no. 2: 217-238.

Hill Collins, Patricia. 2000. Black Feminist Thought: Knowledge, Consciousness, and the Politics of Empowerment. London: Routledge.

Houle, Hortensia. Interview 2016.

Iacovetta, Franca. 2006. Gatekeepers: Reshaping Immigrant Lives in Cold War Canada. Toronto: Between the Lines.

Immigrant Women's Centre. 1977. "Statement by Immigrant Women's Centre, May 10, 1977.” Ontario Archives, Immigrant Women's Organizations files, DSC 0092-0093.

Interviewee O-1. Interview 2017.

Interviewee O-2. Interview 2017.

Interviewee O-3. Interview 2017.

Kinesis. 1979. "Kinesis." Vancouver: Vancouver Status of Women. December 1. doi: http://dx.doi.org/ 10.14288/1.0045587. . 1980. "Mother's Day in the Park." Vancouver: Vancouver Status of Women. . 1982. "Mothers Take Action.” Vancouver: Vancouver Status of Women.

Kohli, Rita. Interview March 22, 2016.

Labelle, Micheleine and Martin Goyette. 1993a. "Report-Intégration économique: Le discours de leaders d'origine haïtienne de la region de Montréal." Département de sociology, UQAM. 
1993b. "Report-Intégration économique: Le discours de leaders d'origine libanaise de la region de Montréal.” Département de sociology, UQAM.

Lior, Karen, ed. 2012. Making the City: Women Who Made a Difference. Halifax: Fernwood Publishing.

Marino, Dian, and Deborah Barndt. 1983. Immigrants Speak Out. Toronto: North York Board of Education.

Marks, Lynne, Margaret Little, Megan Gaucher, and T. R. Noddings. 2016. "'A Job That Should Be Respected': Contested Visions of Motherhood and English Canada's Second Wave Women's Movements, 1970-1990." Women's History Review 25, no. 5: 771790.

Marks, Lynne, Margaret Little, Marin Beck, Emma Paszat, and Taylor Antoniazzi. n.d. "Jesus is not part of this Collective': Secular Passions and Religious Alienation Among the Sisterhood." Second Wave Feminism and Emotions in Canada, edited by Lara Campbell, Catherine Gidney and Mike Dawson. Revised draft submitted to editors.

McKeen, Wendy. 1995. "The Wages for Housework Campaign: Its Contribution to Feminist Politics in the Area of Social Welfare in Canada." Canadian Review of Social Policy 33: 21-43.

Miranda, Susan. Interview March 17, 2016.

Nadasen, Premilla. 2002. "Expanding the Boundaries of the Women's Movement: Black Feminist and the Struggle for Welfare Rights.” Feminist Studies 28, no. 2: $270-301$.

Nann, Beverly. Interview July 25, 2016.

$\mathrm{Ng}$, Roxana, and Judith Ramirez. 1982. Immigrant Housewives in Canada: A Report. Immigrant Women's Centre.

Okada, Tamoka. Interview June 28, 2016.

Passoli, Lisa. 2015. Working Mothers and the Child
Care Dilemma: A History of British Columbia's Social Policy. Vancouver: UBC Press.

Ramirez, Judith. First Interview April 7, 2016.

Ramirez, Judith. Second Interview February 3, 2017.

Razack, Sherene, Malinda Smith, and Sunera Thobani. 2010. States of Race: Critical Race Feminism for the 21st Century. Toronto: Between the Lines.

Ricci, Amanda. 2015. “There's No Place Like Home: Feminist Communities, Social Citizenship and (Un)Belonging in Montreal's Long Women's Movement, 1952-1992." PhD diss., McGill University.

Roth, Benita. 2004. Separate Roads to Feminism. Cambridge: Cambridge University Press.

Sandoval, Chela. 2013. Methodology of the Oppressed. Minneapolis: University of Minnesota Press.

Silvera, Makeda. 1989. Silenced: Talks with Working Class Caribbean Women About Their Lives and Struggles as Domestic Workers in Canada. Sister Vision Press. 1989.

Thobani, Sunera. 2007. Exalted Subjects: Studies in the Making of Race and Nation in Canada. Toronto: University of Toronto Press.

Thompson, Becky. 2002. "Multiracial Feminism: Recasting the Chronology of Second Wave Feminism." Feminist Studies 28, no. 2: 337-360.

Vickers, Jill, Pauline Rankin, and Christine Appelle. 1993. Politics as If Women Mattered: A Political Analysis of the National Action Committee on the Status of Women. Toronto: University of Toronto Press.

Wages for Housework. 1979. WFH Special Issue on Domestics 4, no. 2.

Woodsworth, Ellen. Interview August 16, 2016. 